\title{
An Exploratory Analysis of Mobile Banking Adoption and Consumer Behaviour in Coimbatore City
}

\author{
Syed Ali Fathima S J, M. Mirsath Begum
}

\begin{abstract}
Any type of banking transaction like checking account balance, credit applications, payments and transfers using a smart mobile device or a personal digital assistance is termed as mobile banking which is also referred as M-Banking or SMS Banking. The current study is an attempt to find out how and why people prefer mobile banking for their usage by collecting data from fifty of mobile banking users in Coimbatore city in the month of December 2018. The precise aims of the study are (i) to estimate the consumer's choice in the selection of mobile phones, brand and network, (ii) To find out the extent of mobile banking usage and (iii)To identify the mobile banking knowledge awareness spread among general people or bank customers. The study reveals that mobile banking users are young generation and education has a greater influence in the usage of mobile banking. In the country like India, the analysis revealed that the need for offering customized and enhanced services are essential.
\end{abstract}

Key words: banking, mobile banking, education, customers, data analysis.

\section{INTRODUCTION}

An evolving technology currently being adopted by all the banks in the world is Mobile Banking, a new strategic approach that modernized the operating manners of the Banks towards service delivery to their customers and presenting competition against the other banks. The establishment and availability of financial services at any time and at any place through mobile communication devices is referred as Mobile Banking. The account managing or administration services, any credit or debit bank transaction services, stock market transaction services, customized banking information access services are the scope of mobile banking services.

At the initial period of evolvement, mobile banking services were provided over SMS. The advancement in the development smart phones with wireless application protocol (WAP) enabled the use of the mobile web. European banks are the initiators to provide mobile banking on mobile platform to their consumers in the year 1999.

\section{Mobile banking in India}

In India, mobile banking was started by the HDFC bank in 2003. To enable and enhance the usage of payments using mobile banking, several steps have been taken by the Reserve Bank of India. In order to impart its significance, the central bank has taken the move of removing the transaction limit of Indian Rupees 50,000 and the banks

\footnotetext{
Revised Manuscript Received on September 14, 2019.

Syed Ali Fathima S J, Assistant Professor, Kumaraguru College of Technology, Coimbatore, Tamilnadu, India.(Email: syedalifathima.sj.cse@kct.ac.in)

Dr. M. Mirsath Begum, Assistant Professor, Karpagam Academy of Higher Education, Coimbatore, Tamilnadu, India.(Email:
} drmirsathbegum.m@kahedu.edu.in) were permitted to fix their own transaction limits. In India, a study revealed that the mobile banking services are used by more than 43.7 million users of mobile phones. ICICI Bank stands first with 17.75 million users accessing the mobile banking. The second most are the HDFC subscribers with 9.1 million users followed by 6.13 million subscribers of State Bank of India.

The current study is an attempt to find out how and why people prefer mobile banking for their usage. The study has the following objectives.

\section{OBJECTIVES:}

$>$ To analyze the selected respondent's socio economic profile status.

$>\quad$ To estimate the consumer's choice in the selection of mobile phones, brand and network.

$>\quad$ To discover the extent of mobile banking usage and

$>\quad$ To identify the mobile banking awareness among common people or bank customers.

\section{REVIEW OF LITERATURE}

This section briefly discusses some of the earlier studies conducted on mobile banking.

Sathye (1999) made a study on "Adoption of internet banking by Australian consumers: An Empirical Investigation" and in this study the author stated that the awareness about the product among people is the initial step for either its adaptation or neglecting aspect. Before an user adopts a service or product, knowledge transfer, decision and confirmation are essential. Value for money is the measure opted by consumers to seek the product. Hence, it is requisite that the banks offering this service offer an awareness about its availability and explain the value added services to the consumers providing a comparative study with its competitors. The significance of usage of any service or product can be revealed only through proper advertisements and awareness through reachable channels to the customers. Mobile banking being a new innovative service and fresh experience for the banking users, high awareness would be the major factor that effects its usage.

Black et al (2001) made a qualitative study on the adoption of internet financial services. In his study the author reported that the innovative telecommunication technologies enabled the mobile banking service as a convergence to common people. Several researchers have shown that the attributes of the innovation which are perceived are the major predictors of the decision to adopt a new product or service rather than the innovator characteristics. 
A study on "Using ZMET to explore barriers to the adoption of $3 \mathrm{G}$ mobile banking services" made by Laukkanen and Lauronen (2005) revealed that the locationfree access and the ability to react immediately to the service need are major perceptions of the customers. The establishment of efficiency and convenience in mobile banking service are the significant features to improvise its consumption. In general, an important sponsor feature in mobile banking is the feeling of control. Utilization of time, flexible access and appropriateness builds expediency for customers. The study showed usage convenience was perceived as consumer's ability to effortlessly use and adopt a new product or service.

An article on "Customer perceived value of e-financial services: a means-end approach". Was written by Laukkanen (2006) in which the accuracy of the service or product could be perceived as the consumer's major concern for the service adoption which adds true value and quality of service. The errors or interruptions caused by the service created a major worry on the customer side and it is necessary to ensure the accuracy of the service for enhanced adoptability of the product for such kind of customers.

Dr Amrit Patel (2010) made an analysis on "Harnessing M-banking Potential by Banks in Rural India". In rural areas support low income people to make their financial facility like branch infrastructural requisite. With the use of mobile phones acting as a non-bank retail agent, mobile banking might also help to manage high capacities of less value transactions. The author from his international learning and experiences suggests that the banks in India are required to improve their action with a strategic plan to expose the potentials of mobile banking insisting on customer satisfaction and convenience of its usage at the nominal cost, its access facility and any time availability to the consumers.

Mohammad Taleghani et al. (2011) analysed the "Factors influencing customers' decision to use cell phone banking based on SMS services". This research revealed a study on various factors affecting the mobile banking services from end to end such as speed, adaptability, mobility, accessibility, risk, cost, usability, intention and ease of use variables. The respondents' opinion showed that the degree of risk was the major significant factors followed by speed and self-adaptation affecting the service usage. The study also showed that about seventy-six percentage of variable outputs the intention of improvising the usage of mobile banking services.

With respect to globle, the adoption of mobile banking is highest and certainly trapped up in India and it was stated by Arun Prabhudesai (2012). In 2012, about Seventy-six percentage of smart phone mobile users used mobile banking according to a worldwide survey conducted by the ACI and this percentage was the peak across the world. Only thirty-eight percent from United states and thirty-one present from United Kingdom were the respondents to mobile banking comparatively. With around seventy percent of users, China was the next leading to India followed by sixty-one percent usage in South Africa. The global average of India, the mobile banking service facility could help or transactions with minimum efforts without a separate

adoption rate for mobile banking is around thirty-five percent.

\section{METHODOLOGY}

The current analysis is based on primary data. The structured interview schedule was used for data collection with the 50 users of mobile banking customers. The respondents were selected from Coimbatore city using convenience sampling technique, during December 2018. Among the 50 respondents, 32 (64 percent) are males and the remaining 18 (36 percent) females.

\section{RESULTS AND DISCUSSION}

This section gives the major findings of the current study under three sections. Section I describes the selected socioeconomic and demographic features of the sample respondents. Section II gives a brief account of the banking details of the respondents. Section III deals with the awareness of the respondents on mobile banking and usage of mobile phones among the respondents.

Section I: Socio-Economic \& Demographic Statistics of the Respondents

A clear understanding of the socio-economic and demographic features of the sample units will help in finding out how these factors are related to the mobile banking usage.

Age:

The age wise distribution of the collected data in Table- 1 shows that among the male's majority of 50 percent are in the age group of 21-30 years, and among females about 89 percent come under this age group. Younger generation prefers mobile banking. Taken the sample together 64 percent of the sample units fall under 21-30 years and 24 percent in the age group of 31-40 years.

TABLE-1: Age wise Distribution of the Sample Respondents

\begin{tabular}{|c|c|c|c|c|c|c|}
\hline \multirow[b]{3}{*}{$\begin{array}{c}\text { Age } \\
\text { (vears) }\end{array}$} & \multicolumn{4}{|c|}{ Gender } & \multirow{2}{*}{\multicolumn{2}{|c|}{ Total }} \\
\hline & \multicolumn{2}{|c|}{ Male } & \multicolumn{2}{|c|}{ Female } & & \\
\hline & $\# *$ & $\% *$ & $\# *$ & $\% *$ & $\# *$ & $\%$ * \\
\hline Less than 20 & 4 & 12.5 & 0 & 0 & 4 & 8 \\
\hline $21-30$ & 16 & 50 & 16 & 88.89 & 32 & 64 \\
\hline $31-40$ & 10 & 31.25 & 2 & 11.11 & 12 & 24 \\
\hline above 41 & 2 & 6.25 & 0 & 0 & 2 & 4 \\
\hline Total & 32 & 100 & 18 & 100 & $\mathbf{5 0}$ & 100 \\
\hline
\end{tabular}

*\# represents Number

*\% represents Percentage

Source: Data based on Field survey, 2018 
The findings confirm the study of Nagesh et al., (2011) in which of 62 percent of the persons using mobile banking are in the age group of 18-30 years.

\section{Education:}

The education wise details of mobile banking users of the current study are depicted in the following Table- 2 .

The table reveals that mobile banking users have at least completed higher secondary school level education. Further 76 percent of the respondents have either completed or pursuing under graduation. The findings mirror the finding of earlier study (Suoranta, 2003) in which it was found that the mobile banking users have completed at least intermediate education.

TABLE-2: Education wise Distribution of the Sample Respondents

\begin{tabular}{|c|c|c|c|c|c|c|}
\hline \multirow{3}{*}{ Education } & \multicolumn{4}{|c|}{ Gender } & & \\
\hline & \multicolumn{2}{|c|}{ Male } & \multicolumn{2}{|c|}{ Female } & \multicolumn{2}{|c|}{ Total } \\
\hline & \#* & $\% *$ & $\# *$ & $\% *$ & \#* & $\% *$ \\
\hline \multicolumn{7}{|c|}{ Completed } \\
\hline $\mathrm{HSC}$ & 6 & 18.75 & 4 & 22.22 & 10 & 20 \\
\hline UG & 4 & 12.75 & 12 & 66.67 & 16 & 32 \\
\hline PG & 16 & 50 & 2 & 11.11 & 18 & 36 \\
\hline Total & 26 & 81.5 & 18 & 100 & 44 & 88 \\
\hline \multicolumn{7}{|c|}{ Ongoing } \\
\hline HSC & 2 & 6.25 & 0 & 0 & 2 & 4 \\
\hline UG & 2 & 6.25 & 0 & 0 & 2 & 4 \\
\hline $\mathrm{PG}$ & 2 & 6.25 & 0 & 0 & 2 & 4 \\
\hline Total & 6 & 18.75 & $\mathbf{0}$ & $\mathbf{0}$ & 6 & 12 \\
\hline
\end{tabular}

*\# represents Number

*\% represents Percentage

Source: Data based on Field survey, 2018 (HSC- Higher Secondary School, UG- Under Graduate, PG- Post Graduate)

\section{Occupation:}

The occupation wise details of mobile banking users of the current study are depicted in the following Table-3

TABLE-3: Occupation wise Distribution of the Sample Respondents

\begin{tabular}{|c|c|c|c|c|c|c|}
\hline \multirow[b]{3}{*}{ Occupation } & \multicolumn{4}{|c|}{ Gender } & \multirow{2}{*}{\multicolumn{2}{|c|}{ Total }} \\
\hline & \multicolumn{2}{|c|}{ Male } & \multicolumn{2}{|c|}{ Female } & & \\
\hline & $\# *$ & $\% *$ & $\# *$ & $\% *$ & $\# *$ & $\%$ * \\
\hline Students & 4 & 12.5 & 0 & 0 & 4 & 8 \\
\hline Business & 16 & 50 & 10 & 55.56 & 26 & 52 \\
\hline Professionals & 12 & 37.5 & 4 & 22.22 & 16 & 32 \\
\hline House wife & 0 & 0 & 4 & 22.22 & 4 & 8 \\
\hline Total & 32 & 100 & 18 & 100 & 50 & 100 \\
\hline
\end{tabular}

*\# represents Number

*\% represents Percentage

Source: Data based on Field survey, 2018
Occupation wise analysis reveals that 8 percent are not in labour force, being house wife and 8 percent are students. Majority of 52 percent are doing business and the remaining 32 percent are professionals. Among the male respondents 50 percent are doing the business and this is 55 percent among females. Business people use mobile banking services in a larger proportion. Hamza salim et.al., (2011) reported that 25 percent of the respondents of their study who are mobile banking users are doing business and 16 percentage are students.

\section{Monthly income:}

The income wise distribution of the selected respondents is given in the following Table-4

TABLE-4: Monthly Income wise Distribution of the Sample Respondents

\begin{tabular}{|c|c|c|c|c|c|c|}
\hline \multirow{3}{*}{$\begin{array}{l}\text { Monthly income } \\
\text { (Rs) }\end{array}$} & \multicolumn{4}{|c|}{ Gender } & \multirow{2}{*}{\multicolumn{2}{|c|}{ Total }} \\
\hline & \multicolumn{2}{|c|}{ Male } & \multicolumn{2}{|c|}{ Female } & & \\
\hline & $\# *$ & $\%$ * & $\# *$ & $\% *$ & $\# *$ & $\%$ * \\
\hline $\mathrm{Nil}$ & 4 & 12.5 & 4 & 22.22 & 8 & 16 \\
\hline $5001-15000$ & 8 & 25 & 14 & 77.78 & 22 & 44 \\
\hline $15001-25000$ & 6 & 18.75 & 0 & 0 & 6 & 12 \\
\hline above 25001 & 14 & 43.75 & 0 & 0 & 14 & 28 \\
\hline Total & 32 & 100 & 18 & 100 & 50 & 100 \\
\hline
\end{tabular}

The above Table- 4 shows that 16 percent of the sample respondents are not working. About 44 percent of the respondents have their monthly income in the range of Rs $5001-15000,12$ percent in the range of 15001-25000 followed by 28 percent having their monthly income exceeding Rs 25000. In the case of male respondents, a majority of 43 percent have income exceeding Rs 25001. In the case of female respondents 77 percent have their monthly income in the range of Rs 5001- 15000.

\section{Section II: Bank Details of the Respondents}

Type of bank:

Vitalanalytic (2009) reported that more than the public bank sectors, the mobile banking services are widely used by foreign and private banks. The most prevalent mobile banking service used by urban customers is the account balance checking service. Checking the last three transactions performed and tracking the cheque clearing status are the next preferred services of mobile banking. The following Table-5 gives the type of bank in which the current sample units have their accounts. 
TABLE-5: Type of Bank of the Sample Respondents Type of bank

\begin{tabular}{|c|c|c|c|c|c|c|}
\hline \multirow{3}{*}{ Type of bank } & \multicolumn{4}{|c|}{ Gender } & \multirow{2}{*}{\multicolumn{2}{|c|}{ Total }} \\
\hline & \multicolumn{2}{|c|}{ Male } & \multicolumn{2}{|c|}{ Female } & & \\
\hline & $\# *$ & $\% *$ & $\# *$ & $\% *$ & $\# *$ & $\%$ * \\
\hline Public sector & 12 & 37.5 & 18 & 100 & 30 & 60 \\
\hline Private sector & 10 & 31.25 & 0 & 0 & 10 & 20 \\
\hline Both & 10 & 31.25 & 0 & 0 & 10 & 20 \\
\hline Total & 32 & 100 & 18 & 100 & 50 & 100 \\
\hline
\end{tabular}

*\# represents Number

*\% represents Percentage

Source: Data based on Field survey, 2018

In the current study the sample units have their accounts mostly in public sector banks. This percentage is 37.5 for males and all females have their accounts in public sector banks only. Among males 31.25 percent have their accounts in private sector banks, the remaining either in public sector banks or in both. On enquiry, it was learnt that the public sector banks in which the sample units have their accounts are State Bank of India, Indian Bank, and Corporation Bank. The private sector banks in which the accounts are maintained are HDFC, ICICI and City Union Bank. From Table- 5 it can be seen that majority of 60 percent of the respondents have their accounts in public sector banks only, 20 percent in private sector banks and 20 percent of the respondents use both public and private sector banks. The findings are in tune with the work of Prerna Sharma and Preethi (2011) in which 88 percent of the mobile bank users have their accounts in public sector banks.

\section{Type of banking:}

The following Table- 6 indicates the type of banking preferred by the respondents.

TABLE-6: Type of Banking of the Sample Respondents

\begin{tabular}{|c|c|c|c|c|c|c|}
\hline \multirow{3}{*}{ Type of banking } & \multicolumn{4}{|c|}{ Gender } & \multirow{2}{*}{\multicolumn{2}{|c|}{ Total }} \\
\hline & \multicolumn{2}{|c|}{ Male } & \multicolumn{2}{|c|}{ Female } & & \\
\hline & $\# \star$ & $\% *$ & $\# *$ & $\% *$ & $\# *$ & $\% *$ \\
\hline Traditional & 4 & 12.5 & 4 & 22.22 & 8 & 16 \\
\hline Online & 8 & 25 & 4 & 22.22 & 12 & 24 \\
\hline Mobile & 20 & 62.5 & 10 & 55.56 & 30 & 60 \\
\hline Total & 32 & 100 & 18 & 100 & 50 & 100 \\
\hline
\end{tabular}

*\# represents Number

*\% represents Percentage

Source: Data based on Field survey, 2018
Among the male respondents' majority of 62 percent prefer mobile banking and this percentage among females is 56. Next to this, online banking is the preferred choice for males (25 percent) and females (22 percent). Only 12 percent of the males prefer traditional banking and 22 percent among females.

\section{Types of mobile phones:}

The following Table-7 gives the various types of mobile phones owned by the respondents of the current study.

TABLE-7: Types of Mobile Phones of the Sample Respondents

\begin{tabular}{|c|c|c|c|c|c|c|}
\hline \multirow{3}{*}{$\begin{array}{l}\text { Types of } \\
\text { mobile } \\
\text { phone }\end{array}$} & \multicolumn{4}{|c|}{ Gender } & & \\
\hline & \multicolumn{2}{|c|}{ Male } & \multicolumn{2}{|c|}{ Female } & \multicolumn{2}{|c|}{ Total } \\
\hline & $\# *$ & $\% *$ & $\# *$ & $\%$ * & $\# *$ & $\%$ * \\
\hline $\begin{array}{l}\text { Smart } \\
\text { phones }\end{array}$ & 16 & 50 & 8 & 44.44 & 24 & 48 \\
\hline $\begin{array}{l}3 \mathrm{G} \\
\text { Phones }\end{array}$ & 12 & 37.5 & 2 & 11.11 & 14 & 28 \\
\hline Android & 0 & 0 & 8 & 44.44 & 8 & 16 \\
\hline $\begin{array}{l}\text { Basic } \\
\text { handset }\end{array}$ & 4 & 12.5 & 0 & 0 & 4 & 8 \\
\hline Total & 32 & 100 & 18 & 100 & $\mathbf{5 0}$ & 100 \\
\hline
\end{tabular}

Source: Data based on Field survey, 2018

It can be inferred from Table-7 that each of the respondents own only one mobile phone. Majority of 48 percent own smart phone. Among both males (50 percent) and females (44 percent) preference is for smart phone. The analysis reveals that smart phone is the favourite handset among the public. Females are found to show equal preference for Android mobiles and smart phones.

\section{Brand holding:}

The following Table- 8 gives the brand holding of mobile handset owned by the sample respondents.

TABLE-8: Types of Brand Holding of the Sample Respondents

\begin{tabular}{|l|c|c|c|c|c|c|}
\hline \multirow{2}{*}{ Brand name } & \multicolumn{5}{|c|}{ Gender } & \multicolumn{2}{c|}{} \\
\cline { 2 - 7 } & \multicolumn{2}{|c|}{ Male } & \multicolumn{2}{c|}{ Female } & \multicolumn{2}{c|}{ Total } \\
\cline { 2 - 7 } & $\# *$ & $\% *$ & $\# *$ & $\% *$ & $\# *$ & $\% *$ \\
\hline Samsung & 18 & 56.25 & 8 & 44.44 & $\mathbf{2 6}$ & 52 \\
\hline Nokia & 4 & 12.5 & 6 & 33.33 & 10 & 20 \\
\hline Others & 10 & 31.25 & 4 & 22.22 & 14 & 28 \\
\hline \multirow{2}{*}{ Total } & $\mathbf{3 2}$ & $\mathbf{1 0 0}$ & $\mathbf{1 8}$ & $\mathbf{1 0 0}$ & $\mathbf{5 0}$ & $\mathbf{1 0 0}$ \\
\hline
\end{tabular}

*\# represents Number

*\% represents Percentage

Source: Data based on Field survey, 2018 
The above Table- 8 shows that majority of 52 percent own Samsung brand handset. Both males and females use Samsung mobile in a larger proportion. About 56 percent of the males and 44 percent of the females own Samsung mobile phone. The analysis reveals that Samsung brand is the most favorite mobile among the public followed by Nokia for females and other sets (LG, Motorola) by the males.

\section{Network:}

The following Table-9 gives the types of network used by the respondents.

TABLE-9: Types of Network of the Sample Respondents

\begin{tabular}{|c|c|c|c|c|c|c|}
\hline \multirow[b]{3}{*}{ Network } & \multicolumn{4}{|c|}{ Gender } & \multirow{2}{*}{\multicolumn{2}{|c|}{ Total }} \\
\hline & \multicolumn{2}{|c|}{ Male } & \multicolumn{2}{|c|}{ Female } & & \\
\hline & $\# *$ & $\% *$ & $\# *$ & $\%$ * & $\# \star$ & $\% *$ \\
\hline Reliance & 8 & 25 & 2 & 11.11 & 10 & 20 \\
\hline Airtel & 6 & 18.75 & 12 & 66.67 & 18 & 36 \\
\hline Docomo & 6 & 18.75 & 2 & 11.11 & 8 & 16 \\
\hline BSNL & 4 & 12.5 & 0 & 0 & 4 & 8 \\
\hline Others & 8 & 25 & 2 & 11.11 & 10 & 20 \\
\hline Total & 32 & 100 & 18 & 100 & $\mathbf{5 0}$ & 100 \\
\hline
\end{tabular}

A significant point to be noted in the study is while males show almost equal preference in the network, about 67 percent females are found to prefer 'Airtel'.

\section{Usage of Mobile Banking:}

The respondents were asked to state the period in which they started to use mobile banking. The details are given in the following Table-10

TABLE-10: Usage of Mobile Banking of the Sample Respondents

\begin{tabular}{|c|c|c|c|c|c|c|}
\hline \multirow[b]{3}{*}{$\begin{array}{l}\text { Period of using } \\
\text { mobile banking }\end{array}$} & \multicolumn{4}{|c|}{ Gender } & \multirow{2}{*}{\multicolumn{2}{|c|}{ Total }} \\
\hline & \multicolumn{2}{|c|}{ Male } & \multicolumn{2}{|c|}{ Female } & & \\
\hline & $\# *$ & $\% *$ & $\# *$ & $\% *$ & $\# *$ & $\% *$ \\
\hline Less than 6 months & 12 & 37.5 & 8 & 44.44 & 20 & 40 \\
\hline 6 months -1 year & 4 & 12.5 & 6 & 33.33 & 10 & 20 \\
\hline $1-2$ years & 6 & 18.75 & 0 & 0 & 6 & 12 \\
\hline More than 2 years & 10 & 31.25 & 4 & 22.22 & 14 & 28 \\
\hline Total & 32 & 100 & 18 & 100 & $\mathbf{5 0}$ & 100 \\
\hline
\end{tabular}

The above Table-10 reveals that majority of 40 percent of the respondents started using mobile banking from the past six months only, 20 percent use mobile banking for a period ranging 6 months to one year and 12 percent use mobile banking in one to two years. In the current study a majority of 38 percent of males and 44 percent of females started using mobile banking within the past six months only. Of late an increased preference of using mobile banking is seen among the respondents. The study of Prerna Sharma and preethi (2011) also revealed that of late there is an increase in the frequency of mobile banking users in India.

Section III: Awareness on mobile banking and usage of mobile banking

The following Table-11 gives the source from which the sample units become aware of mobile banking.

TABLE-11: Source of Awareness on Mobile Banking of the Sample Respondents

\begin{tabular}{|c|c|c|c|c|c|c|}
\hline \multirow{3}{*}{$\begin{array}{c}\text { Source of } \\
\text { Awareness } \\
\text { on mobile } \\
\text { banking }\end{array}$} & \multicolumn{4}{|c|}{ Gender } & & \\
\hline & \multicolumn{2}{|c|}{ Male } & \multicolumn{2}{|c|}{ Female } & \multicolumn{2}{|c|}{ Total } \\
\hline & $\# *$ & $\% *$ & $\# *$ & $\%$ * & $\# *$ & $\%$ * \\
\hline Friends & 14 & 43.75 & 6 & 33.33 & 20 & 40 \\
\hline Relatives & 6 & 18.75 & 6 & 33.33 & 12 & 24 \\
\hline Banks & 6 & 18.75 & 2 & 11.11 & 8 & 16 \\
\hline Advertisement & 4 & 12.5 & 2 & 11.11 & 6 & 12 \\
\hline Self & 2 & 6.25 & 2 & 11.11 & 4 & 8 \\
\hline Total & 32 & 100 & 18 & 100 & 50 & 100 \\
\hline
\end{tabular}

The above Table-12 shows that majority of 40 percent become aware of mobile banking through friends, 24 percent from relatives, 16 percent from banks, 12 percent from advertisement and 8 percent through self interest. Among the male respondents' majority of 43 percent know the usage of mobile banking through friends and among female respondents about 66 percent are aware of mobile banking through friends \& relatives. The study reveals that friends are the major source who creates awareness on mobile banking.

The following Table-12 gives the data on the frequency of usage of mobile banking.

TABLE-12: Frequency of Using Mobile Banking Frequency

\begin{tabular}{|c|c|c|c|c|c|c|}
\hline \multirow{3}{*}{$\begin{array}{l}\text { Frequency } \\
\text { of } \\
\text { using } \\
\text { mobile banking }\end{array}$} & \multicolumn{4}{|c|}{ Gender } & \multirow{2}{*}{\multicolumn{2}{|c|}{ Total }} \\
\hline & \multicolumn{2}{|c|}{ Male } & \multicolumn{2}{|c|}{ Female } & & \\
\hline & $\# *$ & $\% *$ & $\# *$ & $\% *$ & $\# *$ & $\% *$ \\
\hline Daily & 0 & 0 & 4 & 22.22 & 4 & 8 \\
\hline Once in a week & 8 & 25 & 2 & 11.11 & 10 & 20 \\
\hline Twice in a month & 10 & 31.25 & 8 & 44.44 & 18 & 36 \\
\hline Once in a month & 12 & 37.5 & 4 & 22.22 & 16 & 32 \\
\hline Rarely & 2 & 6.25 & 0 & 0 & 2 & 4 \\
\hline Total & 32 & 100 & 18 & 100 & 50 & 100 \\
\hline
\end{tabular}

Published By: Blue Eyes Intelligence Engineering \& Sciences Publication 
The above Table-12 shows that majority of 36 percent of the respondents use mobile banking twice in a month, 32 percent once in a month, 20 percent once in a week, 8 percent using mobile banking daily and 4 percent using rarely. Among the male respondents 37 percent use mobile banking once in a month, 44 percent of female respondents use mobile banking twice in a month. Prerna Sharma and Preethi (2011) reported that 45 percent of the people use mobile banking once in a week.

\section{Mobile Phone Facilities:}

Various facilities are available in mobile phones. But how far the users are using it is a question mark. Hence the customers are asked to state the various facilities that they use in mobile phones. The following table -13 gives the details on the facilities which are used by the respondents.

TABLE - 13: Classification of the Respondents Based on the Use of Mobile Phone Facilities

\begin{tabular}{|c|c|c|c|c|c|c|}
\hline \multirow[b]{2}{*}{ Items } & \multicolumn{2}{|c|}{ Male } & \multicolumn{2}{|c|}{ Female } & \multicolumn{2}{|r|}{ All } \\
\hline & $\begin{array}{l}Y \\
\text { es }\end{array}$ & $\begin{array}{c}\text { Percent } \\
\text { age }\end{array}$ & $\begin{array}{l}Y \\
\text { es }\end{array}$ & $\begin{array}{c}\text { Percent } \\
\text { age }\end{array}$ & $\begin{array}{l}\mathbf{Y} \\
\text { es }\end{array}$ & $\begin{array}{c}\text { Percent } \\
\text { age }\end{array}$ \\
\hline $\begin{array}{l}\text { Making } \\
\text { calls }\end{array}$ & 32 & 100 & 18 & 100 & 50 & 100 \\
\hline Banking & 32 & 100 & 18 & 100 & 50 & 100 \\
\hline SMS & 30 & 93.75 & 18 & 100 & 48 & 96 \\
\hline Photos & 30 & 93.75 & 14 & 55.55 & 44 & 88 \\
\hline Music & 24 & 75 & 14 & 77.77 & 38 & 76 \\
\hline Internet & 26 & 81.25 & 10 & 77.77 & 36 & 72 \\
\hline Games & 24 & 75 & 12 & 55.55 & 36 & 72 \\
\hline Email & 22 & 68.75 & 8 & 44.44 & 30 & 60 \\
\hline $\begin{array}{l}\text { Social } \\
\text { network } \\
\text { sites }\end{array}$ & 22 & 68.75 & 8 & 44.44 & 30 & 60 \\
\hline $\begin{array}{l}\text { Downloa } \\
\text { ding } \\
\text { applicatio } \\
\text { ns }\end{array}$ & 20 & 6.25 & 8 & 44.44 & 28 & 56 \\
\hline Maps & 16 & 50 & 6 & 33.33 & 22 & 44 \\
\hline $\begin{array}{l}\text { Watching } \\
\text { videos/T } \\
\text { V }\end{array}$ & 18 & 56.25 & 4 & 22.22 & 22 & 44 \\
\hline $\begin{array}{l}\text { News/we } \\
\text { ather }\end{array}$ & 12 & 37.75 & 4 & 22.22 & 16 & 32 \\
\hline $\begin{array}{l}\text { Looking } \\
\text { up prices } \\
\text { for } \\
\text { products }\end{array}$ & 8 & 25 & 0 & 0 & 8 & 16 \\
\hline $\begin{array}{l}\text { Buying } \\
\text { product }\end{array}$ & 8 & 25 & 0 & 0 & 8 & 16 \\
\hline
\end{tabular}

Source: Data based on field survey, 2018

The above Tabe-13 shows that both the male (100 percent) and female (100 percent) respondents use mobile phone for 'making calls' and for 'banking' purposes. All the female respondents (100 percent) are using 'SMS' facility and this percentage among the male was about 94 percent. Next to it about 81 percent of the males and 77 percent of females are accessing internet in mobile phone. Nearly 65 to 75 percent of males and 45 to 55 percent of females are using 'games', 'email' and 'social network sites' in their mobile phones.

The analysis reveals that the cell phone users are mostly using it for 'making calls', 'SMS', 'banking', 'internet', 'games', 'email', and social network sites facilities in cell phones. A noteworthy feature is that nearly 25 percent of males use mobile phones for buying products while this was zero percentage among females.

\section{Mobile Banking Activities:}

There are wide range of mobile banking services offered by different banks. Few significant mobile banking services are transfer of amount, balance enquiry, view and download credit and debit transaction activities, mobile payments, usage of loyalty and ticketing applications with vouchers and e-coupons. The following Table -14 gives the details on the mobile banking activities used by the respondents.

TABLE - 14: Classification of the Respondents Based on the Use of Mobile Banking Activities

\begin{tabular}{|c|c|c|c|c|c|c|}
\hline \multirow[b]{2}{*}{ ITEMS } & \multicolumn{2}{|c|}{ Male } & \multicolumn{2}{|c|}{ Female } & \multicolumn{2}{|r|}{ All } \\
\hline & $\begin{array}{c}\text { Ye } \\
\text { s }\end{array}$ & $\begin{array}{l}\text { Percent } \\
\text { age }\end{array}$ & $\begin{array}{c}\text { Ye } \\
\text { S }\end{array}$ & $\begin{array}{l}\text { Percent } \\
\text { age }\end{array}$ & $\begin{array}{c}\text { Ye } \\
\text { s }\end{array}$ & $\begin{array}{l}\text { Percent } \\
\text { age }\end{array}$ \\
\hline \multicolumn{7}{|l|}{ Personal use } \\
\hline $\begin{array}{l}\text { SMS alert on bank } \\
\text { transaction }\end{array}$ & 28 & 87.5 & 18 & 100 & 46 & 92 \\
\hline $\begin{array}{l}\text { Download MB } \\
\text { applications }\end{array}$ & 20 & 62.5 & 8 & 44.44 & 28 & 56 \\
\hline $\begin{array}{l}\text { Access card } \\
\text { statement }\end{array}$ & 16 & 50 & 4 & 22.22 & 20 & 40 \\
\hline Locate ATM & 16 & 50 & 2 & 11.11 & 18 & 36 \\
\hline Mobile recharging & 8 & 25 & 6 & 33.33 & 14 & 28 \\
\hline Pay electricity bill & 4 & 12.50 & 2 & 11.11 & 6 & 12 \\
\hline $\begin{array}{l}\text { Buy stocks or } \\
\text { mutual funds }\end{array}$ & 6 & 18.75 & 0 & 0 & 6 & 12 \\
\hline $\begin{array}{l}\text { PIN provision, } \\
\text { change of PIN }\end{array}$ & 4 & 12.50 & 2 & 11.11 & 6 & 9 \\
\hline $\begin{array}{l}\text { Sell stocks or } \\
\text { mutual funds }\end{array}$ & 4 & 12.50 & 0 & 0 & 4 & 8 \\
\hline \multicolumn{7}{|l|}{ Banking } \\
\hline $\begin{array}{l}\text { Check balance } \\
\text { account }\end{array}$ & 26 & 81.25 & 16 & 88.88 & 42 & 84 \\
\hline $\begin{array}{l}\text { Check last } \\
\text { transaction only }\end{array}$ & 24 & 75 & 14 & 77.77 & 38 & 76 \\
\hline $\begin{array}{l}\text { Transfer money } \\
\text { between two } \\
\text { accounts }\end{array}$ & 20 & 62.5 & 8 & 44.44 & 28 & 56 \\
\hline $\begin{array}{l}\text { View fixed deposit } \\
\text { details }\end{array}$ & 16 & 50 & 2 & 11.11 & 18 & 36 \\
\hline $\begin{array}{l}\text { View last three } \\
\text { transactions }\end{array}$ & 18 & 56.25 & 0 & 0 & 18 & 36 \\
\hline $\begin{array}{l}\text { Cheque book } \\
\text { request }\end{array}$ & 12 & 37.50 & 4 & 22.22 & 16 & 32 \\
\hline $\begin{array}{l}\text { Request bill } \\
\text { payment }\end{array}$ & 12 & 37.50 & 2 & 11.11 & 14 & 28 \\
\hline $\begin{array}{l}\text { Enquiry for cheque } \\
\text { status }\end{array}$ & 12 & 37.50 & 0 & 0 & 12 & 24 \\
\hline Repayment of loan & 6 & 18.75 & 2 & 11.11 & 8 & 16 \\
\hline $\begin{array}{l}\text { Pass book } \\
\text { updation }\end{array}$ & 6 & 18.75 & 2 & 11.11 & 8 & 16 \\
\hline $\begin{array}{l}\text { Stop payment on } \\
\text { cheque }\end{array}$ & 4 & 12.50 & 0 & 0 & 4 & 8 \\
\hline $\begin{array}{l}\text { Demand draft } \\
\text { (DD) }\end{array}$ & 2 & 6.25 & 0 & 0 & 2 & 4 \\
\hline
\end{tabular}

Majority of 92 percent of the respondent's view 'SMS alert' in mobile phones. Next to it 84 percent of the respondents 'check the account balance', 76 percent 'check the recent transaction' statement and 4 percent of the respondents send demand draft through cell phone. Among the male respondents 87 percent of the respondents see 'SMS alert', 81 percent 'check the account balance' and about 62 percent download mobile banking applications and transfer money between two accounts. Among the females all (100 percent) are using mobile phones to see 'SMS alert', 88 percent are 'checking account balance' and 11 percent of

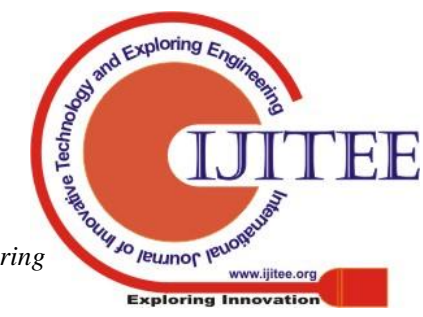


the respondents each 'view fixed deposit details', 'locate ATM branch', 'request bill payment', 'repayment of loan', 'pass book updation', 'electricity bill payment' and 'PIN provision or change of PIN'.

The analysis reveals that majority of the respondents use mobile phones for 'SMS alert', 'account balance checking', 'check the recent transactions', 'downloading mobile banking applications' and to 'transfer money between two accounts.

\section{CONCLUSION}

The present study shows that younger generation of people use mobile banking services in a greater proportion. Further it is learnt that the higher influence was seen in education domain for the mobile banking usage. There is always, there is a requirement for offering customized and enhanced services to the ever growing and demanding customers in the country like India. The adaptation of new services using modern technology seems to be reluctant at the initial stage to the customers It is the responsibility of the service providers in this case the banks to ensure and educate the the safe use of mobile banking services as that of traditional banking, emphasizing the convenience of mobile banking usage to the treasurable consumers.

\section{BIBLIOGRAPHY}

1. M.sathye (1999) "adoption of Internet banking by Australian consumers: An empirical investigation," International Journal of Bank Marketing, Vol.17, no.7, pp: 324-334

2. Mohammad Taleghani, Shahram Gilaninia,AdelRouhi \& Seyyed Javad Mousavian(2011)"Factors influencing on customers' decision to use of cell phone banking based on SMS services". Interdisciplinary journal of contemporary research in business, vol:3, No:5, pp:86-97

3. Black, N., Lockett, A., Winklhofer, H., \& Ennew, C. (2001). The adoption of Internet financial services: a qualitative study. International Journal of Retail \& Distribution Management, 29(8), 390-398.

4. Thomas, Friedman (November 2, 2010). "Do Believe the Hype". New York Times

5. Solomon negash, peter. N and Gamel.O (2011) "Mobile Banking Adoption in the United States: adapting mobile banking features from low income countries", Proceeding of SIG GlobDev Fourth Annual Workshop, Sanghai, China December 3rd, 2011.

6. Prerna Sharma bamoriya and preethi singh (2011) "Issues \& Challenges in Mobile Banking in India: a Customer's Perspective", Research journal of finance and accounting ISSN 2222-1697 (paper) ISSN 2222-2847 (online) Vol 2, No: 2, 2011.

7. Hamza salim khraim, Younes ellyan and Aymen salim khraim (2011) "Factors Affecting Jordanian Consumer's Adoption of Mobile Banking Service", International Journal of Business and Social Science, Vol.2, No: 20, November 2011.

8. http://www.ukessays.com/essays/marketing/factors-inacceptance-of-mobile-banking-in-india-marketingessay.php\#ixzz2IbHJMhcy

9. (http://trak.in/tags/business/2012/05/15/india-mobilebanking-payment-adoption/)

10. Balakrishnan, Nagaraj, Arunkumar Rajendran, and Karthigaikumar Palanivel. "Meticulous fuzzy convolution $\mathrm{C}$ means for optimized big data analytics: adaptation towards deep learning." International Journal of Machine Learning and Cybernetics (2019): 1-12.
11. www.microfinancegateway.org/gm/...1.9.../ARP-RCNABARD-3.pdf

12. http://blog.pac-online.com/2012/10/mobile-banking-inindia-public-sector-banking-is-leading-the-race/

13. http://www.mobilefiblog.com/javelin-consumer-securityeducation-needed-for-mobile-banking/. 